\title{
A Administração Pública e seus Técnicos
}

ADA uma das diferentes fases da vida da humanidade contribitiu para a evolução do Estado, mediante novas idéias que the enriqueceram o conceito ou novos instrumentos que the aperfeiçoaram as atividades.

Os tempos que antecederam a civilização helênica produziram a concepção da oriǵem e legitimidade do poder que serviu de base ao chamado Estado Oriental. Da Grécia de ARIstóteles vieram os primeiros estudos de interpretação politica, as primeiras classificações dos organismos estatais, a idéia da identificação entre a comunidade e a autoridade suprema do Estado. Da velha Roma promanou a sistematização dos aspectos jurídicos das questões políticas, a clara distinção das personalidades jurídicas do Estado e do cidadão, a determinação do exato conteúdo das relações de direito público interno e externo, a noção de imperium que ainda agora domina o campo da teoria politica. O próprio Feudalismo, hoje tão malsinado, produziu os lineamentos básicos do mecanismo dos governos locais e emprestou maior significação ao elemento territorial na organização política dos povos. O espírito especulativo do Renascimento, estimulado pela repulsa ao dogma e ao artigo de fé, empreendeu a análise das teses e das instituições politicas, negando a origem divina do poder, quebrando a pedra angular dos Estados absolutistas e abrindo o caminho pelo qual os enciclopedistas enveredariam mais tarde para chegar à concepção de soberania como atributo da nacionalidade e à de mandato popular como processo legítimo de constituição do govêrno.

Os tempos modernos trouxeram à organização do Estado um elemento novo, a técnica, em função da qual os serviços públicos adquiriram características desconhecidas de outras épocas. A técnica influenciou o Estado em dois sentidos: ampliando-1he o campo das atividades opcionais e impondo-1he um apareilhamento administrativo mais complexo. 
Não tivesse o Estado se revelado capaz de assimilar as conquistas da técnica e de colocá-las a serviço dos interêsses coletivos, sua posição, em face das grandes concentrações do poder econômico com que essa mesma técnica fortaleceu o elemento privado, seria insustentável.

Quando encarado em face do problema do equilibrio das fôrças sociais, o tecnicismo do Estado surǵe com o caráter de um fator de sobrevivência. Assim como não se compreende que, a partir dos fins do século XVIII, o Estado prescinda da idéia de soberania popular, também não se concebe possa êle, em plena fase do industrialismo, organizar-se e funcionar sem recorrer ao auxílio da técnica. MANNHEIM traduziu em têrmos incisivos e claros a alternativa com que se defrontam as organizações politicas dos povos nos dias que correm: "sobreviver com a técnica ou desaparecer sem ela".

Uma das primeiras conseqüências da introdução da técnica entre os elementos vitais do Estado foi a constituição, dentro dos quadros do funcionalismo, de um corpo de elite capaz de levar a bom têrmo as tarefas especializadas inerentes à formulação, execução e revisão dos planos e atividades governamentais. Os elementos dessa elite são, em geral, pessoas dotadas de cultura de nível universitário e, portanto, já preparadas para o exercício profissional em setores nos quais o Estado sofre a concorrência de instituições privadas que com êle disputam um mercado de traba1ho deficitário. Em alguns de tais setores, a impetuosa expansão das instituições privadas e a maior flexibilidade que estas imprimem à sua política de recrutamento estão criando para o Estado, que não tem sabido proteger-se com providências adequadas, uma situação cujas conseqüências danosas muito cedo serão duramente sentidas. Pouco a pouco os quadros de pessoal técnico do serviço público se estão empobrecendo, pela evasão dos seus elementos mais experientes e credenciados.

A drenagem de cultura e de experiência do serviço público para as instituições privadas tende a enfraquecer a posição do Estado em face das diversas formas de concentração do poder econômico, as quais, através do insidioso processo de desfalque da elite intelectual do funcionalismo, estão adquirindo novos e importantíssimos elementos de fòrça. 
Êsse fenômeno assume feição tanto mais inquietante quando se considera que as instituições privadas, cada vez mais rebeldes à ação normativa do Estado, já desfrutam de uma organização mais flexível e, portanto, de mais pronta e eficiente adaptação às variações da realidade social, e já dispõem de um regime de operações que desconhece o sistema de contrôles múltiplos e rígidos que tanto entorpece a administração pública.

Antes que os fatos culminem nos graves malefícios que desde agora podem ser nitidamente previstos, a administração pública deve promover a revisão de sua politica de pessoal, no sentido de restabelecer o princípio de hierarquia das profissões e assegurar às carreiras técnicas de nível superior situação compatível com o papel que thes cabe desempenhar na vida do Estado moderno.

Noutra oportunidade, comentando os resultados do concurso para a carreira de Técnico de Administração, aludimos ao assunto e se a êle voltamos agora é pela convicção que temos de que o problema não envolve, apenas, o interêsse de algumas categorias de funcionários, mas o da própria normalidade da vida do serviço público. Êste não pode, nos diversos campos em que opera, perder a liderança intelectual e técnica, base imprescindível ao seu prestígio e fator fundamental de sua eficiência. 